\title{
Testing the modified CREAMS/GLEAMS model for pesticide concentration in soil
}

\author{
Simo Salo, Maximilian Posch and SePpo ReKolainen
}

\begin{abstract}
Salo, S., Posch, M. \& Rekolainen, S. 1994. Testing the modified CREAMS/ GLEAMS model for pesticide concentration in soil. Agricultural Science in Finland 3: 59-68. (Water and Environment Research Institute, P.O.Box 250, FIN-00101 Helsinki, Finland.)
\end{abstract}

\begin{abstract}
The accuracy of simulating the trifluralin concentrations in a clay soil and in a loamy sand soil with the modified CREAMS/GLEAMS model has been tested by comparing them with observed values. The simulated concentrations in the soils were in good agreement with those observed in the first weeks after application. In the long run the simulated concentrations decreased faster than the observed ones. In addition, the sensitivity of the model to variations of two pesticide parameters has been analyzed: the pesticide adsorption coefficient for organic carbon and the pesticide degradation rate expressed as half-life in soil. The variation in the two pesticide parameters had a considerable effect on the model output. Especially large were the effects of the adsorption coefficient on the pesticide concentration in the percolated water leaving the root zone.
\end{abstract}

Key words: agriculture, transport, degradation

\section{Introduction}

The pesticides used in agriculture are a potential source of pollution of groundwater and surface waters. A total of 4253 tons of pesticides containing 1741 tons of active ingredients and more than 200 products were sold in Finland in 1991 (HYNNINEN and BLOMQVIST 1992). At present, the assessment of the environmental impacts of pesticides in the context of the official approval procedure is almost exclusively based on laboratory tests provided by the producers and importers. Since the testing of the persistence and leaching of all pesticides under variable field conditions during several years is an overwhelming task, the use of mathematical simulation models is a quick and inexpensive way of investigating the fate of a particular pesticide.
Several models have been developed to predict the chemical leaching from soil to surface waters and groundwater. For example, in a review published by the Organisation for Economic Co-operation and Development (OECD Environment Directorate 1989), seven models concerning the fate of chemicals in soils have been described: two Dutch models, PSM and ONZAT, the German model EXSOL, and four American models, PRZM, SESOIL-4, SOLUTE and AT123D. All these models describe the movement of water and solutes through a (vertical) soil column and/or in groundwater, but none of them considers erosion caused by overland flow. Also models like the Swedish MACRO (JARVIS 1991) and LEACHMP (WAGENET and HUTSON 1986) fall into this category. However, pesticide transport to surface waters via erosion should also 
be considered when assessing the environmental impacts of pesticides.

Only few models consider both the movement through the soil column and the transport in the runoff and the eroded material. One of the most widely used models of this type is the CREAMS model (KNISEL 1980) and its extension GLEAMS (LEONARD et al. 1987). This model has been adapted to Finnish conditions (KALLIO et al. 1989, REKOLAINEN and POSCH 1993) and has been used e.g. for assessing the environmental effects of different management practices in Finland (REKOLAINEN et al. 1993).

One of the purposes for selecting and testing a pesticide transport model was the need of a tool for screening (new) pesticides with respect to their environmental behaviour in the context of the legal approval procedure in Finland. Therefore, a userfriendly interface was developed which allows also the non-technical user to apply the model (SALO et al. 1993). The model has also been used to assess the risk of pesticide leaching to surface waters (REKOLAINEN and POSCH 1992).

The aim of this study was to test the ability of the modified CREAMS/GLEAMS model for simulating pesticide concentrations in soil, using field data from Jokioinen in South-Western Finland for comparison. In addition, the sensitivity of the model simulations with respect to two key pesticide parameters was investigated.

\section{Model description}

CREAMS/GLEAMS is a field scale model which estimates surface runoff, evapotranspiration and percolation volumes as well as the erosion from daily rainfall and temperature data. The surface runoff is estimated by the U.S. Soil Conservation Service (SCS) Curve Number Method (U.S. Department of Agriculture 1972) and the evapotranspiration is computed according to RITCHIE (1972); the amount of eroded material is calculated by the Universal Soil Loss Equation (USLE) (WISCHMEIER and SMITH 1978).

The main modifications of the CREAMS/ GLEAMS model to adapt it to Finnish conditions are the implementation of a plant growth model based on the WEPP (Water Erosion Prediction Project) formulations (LANE and NEARING 1989), a new snow accumulation and melt routine and the calculation of the rainfall erosivity in the USLE based on Finnish breakpoint rainfall data (PosCH and REKOLAINEN 1993).

In the pesticide module the partitioning of the pesticide between the aqueous and solid phase at equilibrium is described by a linear adsorption isotherm,

$$
\text { (1) } \mathrm{K}_{\mathrm{d}}=\frac{\mathrm{C}_{\mathrm{s}}}{\mathrm{C}_{\mathrm{w}}}
$$

where $\mathrm{K}_{\mathrm{d}}$ is the adsorption coefficient $\left(\mathrm{ml} \mathrm{g}^{-1}\right), \mathrm{C}_{\mathrm{s}}$ is the pesticide concentration in solid phase $(\mathrm{mg}$ $\mathrm{kg}^{-1}$ ) and $\mathrm{C}_{\mathrm{w}}$ is the pesticide concentration in water phase $\left(\mathrm{mg} \mathrm{l}^{-1}\right)$. The model assumes a non-ionic pesticide and the adsorption occurs only on organic carbon. The adsorption coefficient $\mathrm{K}_{\mathrm{d}}$ is calculated from the adsorption coefficient for organic carbon, $\mathrm{K}_{\mathrm{oc}}\left(\mathrm{ml} \mathrm{g}^{-1}\right)$, by

$$
\mathrm{K}_{\mathrm{d}}=\mathrm{K}_{\mathrm{oc}} \cdot \mathrm{OC}
$$

where $\mathrm{OC}$ is the fraction of organic carbon in the soil. OC, in turn, is related to the fraction of soil organic matter OM via $\mathrm{OM}=1.724 \mathrm{OC}$. The maximum concentration in the water phase is limited by the water solubility of the pesticide.

In addition to the pesticide directly reaching the soil surface during application, the concentration of the pesticide in the surface layer of the soil is increased by washoff from foliage, and the total pesticide concentration in the soil is reduced due to biological and chemical degradation. The rate of pesticide degradation is described by a first-order rate equation

$$
C_{\text {Soil }}(\mathrm{t})=\mathrm{CS}_{\text {Soil }}(0) \mathrm{e}^{-0.693 \mathrm{t} / \mathrm{t}_{1 / 2}}
$$

where CSoil( $\mathrm{t}$ ) is the pesticide concentration in the soil at time t, $\mathrm{CS}_{\text {Soil }}(0)$ is the initial pesticide concentration and $t_{1 / 2}$ is the half-life of the pesticide.

A certain amount of the pesticide percolates with the water flux to the lower soil layers and finally 
leaves the deepest soil layer (below the root zone). This amount is also exposed to plant transpiration and to the transport induced by water evaporation. The remaining pesticide in the soil surface is subject to removal by surface runoff and sediment loss due to erosion. In CREAMS/GLEAMS it is assumed that some mass of the soil surface layer is effective in supplying pesticide to the flow. In this soil mass the mass of pesticide is the product of the runoff-available concentration, $\mathrm{C}_{\mathrm{av}}$, and an extraction coefficient B. Since it is assumed that the pesticide equilibrates (instantly) between the soil mass and the overland flow, we have

(4) $\mathrm{C}_{\mathrm{w}}+\mathrm{C}_{\mathrm{s}} \mathrm{B}=\mathrm{C}_{\mathrm{av}} \mathrm{B}$

Together with Eq.(1) this allows to calculate the concentration in soil and water as a function of $\mathrm{C}_{\mathrm{av}}$ at every time step (day). The extraction coefficient $\mathrm{B}$ is modeled as a function of the adsorption coefficient $\mathrm{K}_{\mathrm{d}}$ and varies from 0.1 to $0.5 \mathrm{~g} \mathrm{~m}^{-1}$ (LEONARD et al. 1987).

In the model input and output the pesticide quantities are expressed as mass per soil area (e.g. g $\mathrm{ha}^{-1}$ ), whereas the internal calculations are based on concentrations (e.g. $\mu \mathrm{g} \mathrm{g}^{-1}$ ). The transformation between these two units is accomplished by the following equation:

$$
x_{P}=\rho_{S}(1-f) \cdot z \cdot C_{\text {Soil }}
$$

where $x_{P}$ is the mass of pesticide per unit area of soil, $\rho_{\mathrm{S}}$ is the mean soil particle density, $\mathrm{f}$ is the soil porosity, $\mathrm{z}$ is the thickness of the soil layer and $\mathrm{C}_{\text {Soil }}$ is the pesticide concentration in soil.

Three methods for pesticide application are implemented in the model: (1) surface application: the pesticide is mixed into surface layer (defined as the top $1 \mathrm{~cm}$ layer); (2) incorporation: the pesticide is mixed into the top layers down to a given mixing depth; and (3) injection: the pesticide is mixed into the soil layer defined by the injection depth. The uppermost $1 \mathrm{~cm}$ soil layer contributes to the pesticide in runoff. A more detailed description of the model can be found in KNISEL (1980) and LEONARD et al. (1987).

\section{Data material}

The data for testing the pesticide module of the modified CREAMS/GLEAMS model was taken from an experimental study carried out during 1987 in Jokioinen ( $\left.23^{\circ} 30^{\prime} \mathrm{E}, 60^{\circ} 49^{\prime} \mathrm{N}\right)$ in South-Western Finland (BRAUNSCHWEILER 1992a). The experiments were conducted on a clay soil (Site1) and a loamy sand soil (Site 2) (Table 1). The crop was turnip rape planted on May 25 in the loamy sand soil and on June 2 in the clay soil.

The pesticide, trifluralin, was incorporated into the top $4 \mathrm{~cm}$ layer on the planting days, and the amount was $0.96 \mathrm{~kg} \mathrm{ha}^{-1}$ on both soils. Trifluralin (2,6-Dinitro-N,N-dipropyl-4-trifluoro-methylaniline) is used for the pre-emergence control of annual grasses and broad-leaved weeds. In Finland it has been in use since 1974, and the amount of active ingredient sold in 1992 was 16.69 tons. The major application in Finland is on oil-seed cultivations. In the simulation, a value of $932 \mathrm{ml} \mathrm{g}^{-1}$ for the adsorption coefficient for organic carbon was used. This value has been estimated from the octanol/water partitioning coefficient of trifluralin (RAO and DAVIDSON 1980). The applied half-life of trifluralin is 132 days (RAO and DAVIDSON 1980), and the water solubility of trifluralin at $25^{\circ} \mathrm{C}$ is $4.0 \mathrm{mg} \mathrm{l}^{-1}$ (NIKUNEN et al. 1990).

Table 1. Soil characteristics of the two sites used in this study.

\begin{tabular}{|c|c|c|c|}
\hline Variable & Unit & $\begin{array}{l}\text { Site } 1 \\
\text { (clay) }\end{array}$ & $\begin{array}{c}\text { Site } 2 \\
\text { (loamy sand) }\end{array}$ \\
\hline Clay content & $\%$ & 64 & 15 \\
\hline Silt content & $\%$ & 26 & 5 \\
\hline Sand content & $\%$ & 10 & 80 \\
\hline Organic matter content & $\%$ & 9.2 & 4.0 \\
\hline Bulk density & $\mathrm{g} \mathrm{cm}^{-3}$ & 0.9 & 1.0 \\
\hline Particle density & $\mathrm{g} \mathrm{cm}^{-3}$ & 2.6 & 2.7 \\
\hline Porositya & - & 0.65 & 0.63 \\
\hline Hydraulic conductivity & $\mathrm{mm} \mathrm{h}^{-1}$ & 0.3 & 10.0 \\
\hline Field capacity & - & 0.39 & 0.19 \\
\hline Wilting point & - & 0.28 & 0.05 \\
\hline SCS curve number ${ }^{b}$ & - & $80-95$ & $68-81$ \\
\hline
\end{tabular}

a Computed from bulk density and particle density.

b Varies with crop stage. 

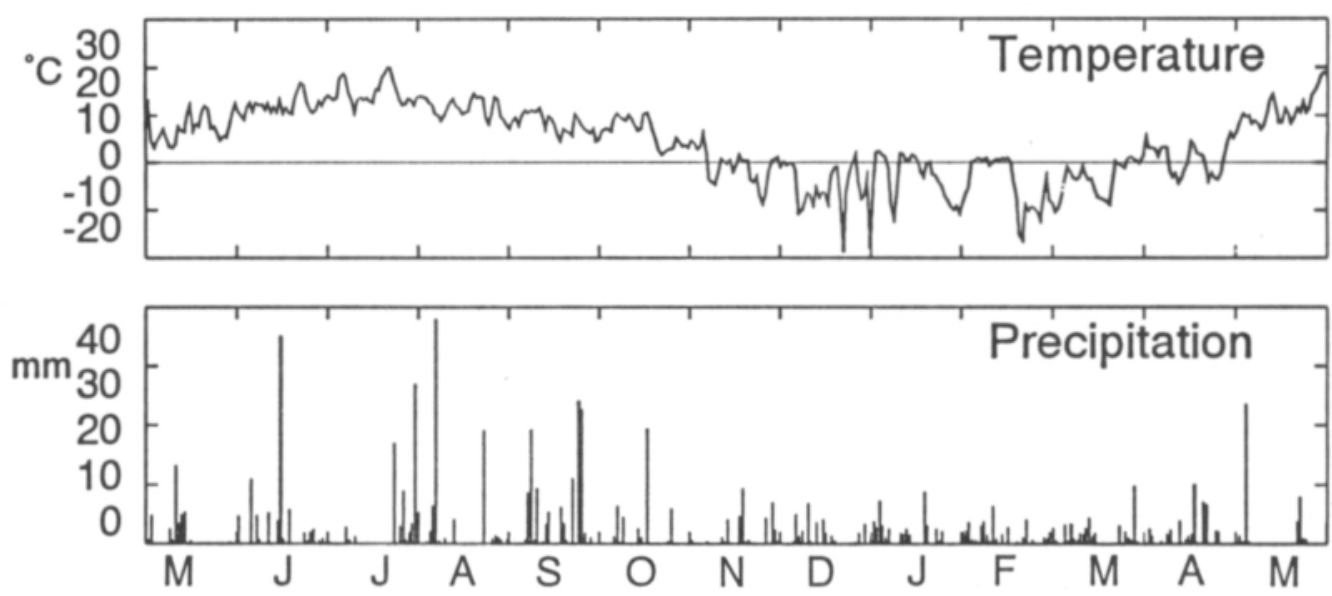

Fig. 1. Daily air temperature $\left({ }^{\circ} \mathrm{C}\right)$ and precipitation $(\mathrm{mm})$ in Jokioinen from May 1987 to May 1988.

The trifluralin concentrations were measured in three soil layers: $0-5 \mathrm{~cm}, 5-15 \mathrm{~cm}$ and $15-25 \mathrm{~cm}$ (values from 4-5 subsamples in each layer which were mixed and homogenized); and the model simulations are reported for the same layers. The samples were taken 1 day, 30 days and 132 days after the pesticide application from the clay soil; and 1day, 31 days and 140 days after application from the loamy sand. Measurements from an untreated control plot were used as blanks in order to eliminate the effects of interfering compounds and residues (BRAUNSCHWEILER 1992a).

For daily temperature and precipitation, the 1987 values observed at the Jokioinen Meteorological Observatory were used (Fig. 1). Other model parameter values were taken from tables reported in the CREAMS manual (KNISEL 1980) and earlier calibrations of the hydrology and erosion submodels from Jokioinen (REKOLAINEN and POSCH 1993). Due to the lack of more detailed information, the plant-related parameters used in the model were taken to be similar to the ones of barley (LANE and NEARING 1989).

In addition to the simulation of the experiments described above, a sensitivity analysis of the pesticide model was carried out for a loamy soil (15\% clay, $50 \%$ silt and $35 \%$ sand) using the weather input variables from Jokioinen (1987/88) (Fig. 1). The sensitivity of four output variables - (1) pesti- cide concentration in the top $7.5 \mathrm{~cm}$ of the soil, (2) pesticide leaching in runoff, (3) pesticide loss in eroded sediment and (4) pesticide leaching in percolation water below the rooting zone - on two model parameters was studied. These parameters were the adsorption coefficient $\mathrm{K}_{\mathrm{oc}}$ and the half-life of the pesticide $t_{1 / 2}$. The sensitivity was studied by varying one of these two parameters at a time, while keeping the other at the trifluralin value given above. The range for the adsorption coefficient was $50-2000 \mathrm{ml} \mathrm{g}^{-1}$, and $\mathrm{t}_{1 / 2}$ was varied between 10 and 1000 days, i.e. about one week to three years.

\section{Results}

The observed and simulated trifluralin concentrations in each soil layer in the clay soil and in the loamy sand soil are presented in Table 2 and Figure 2 . In the clay soil the observed concentrations in the top $5 \mathrm{~cm}$ layer were clearly higher than the predicted ones. The observed concentration on the first day after application was even higher than the theoretical mean concentration in the $5 \mathrm{~cm}$ topsoil layer $\left(2.1 \mu \mathrm{g} \mathrm{g}^{-1}\right)$, calculated from the application rate of $0.96 \mathrm{~kg} \mathrm{ha}^{-1}$ and the estimated soil bulk density of $0.9 \mathrm{~g} \mathrm{~cm}^{-3}$.

In the $5 \mathrm{~cm}$ top layer of the loamy sand soil the observed and simulated trifluralin concentrations 
Table 2. Observed (obs) and simulated (sim) trifluralin concentrations [ $\left.\mu \mathrm{g} \mathrm{g}^{-1}\right]$ in clay and loamy sand soils in three soil layers 1 day, 30/31 days and 132/140 days after trifluralin application.

\begin{tabular}{|c|c|c|c|c|c|c|}
\hline \multirow{2}{*}{$\frac{\text { CLAY }}{\text { Layer }}$} & \multicolumn{2}{|c|}{1 day } & \multicolumn{2}{|c|}{30 days } & \multicolumn{2}{|c|}{132 days } \\
\hline & obs & $\operatorname{sim}$ & obs & $\operatorname{sim}$ & obs & sim \\
\hline $0-5 \mathrm{~cm}$ & 2.7 & 1.7 & 2.1 & 1.4 & 1.8 & 0.8 \\
\hline $5-15 \mathrm{~cm}$ & 0.05 & 0.00 & 0.1 & 0.01 & 0.04 & 0.02 \\
\hline $15-25 \mathrm{~cm}$ & 0.04 & 0.00 & 0.005 & 0.000 & 0.01 & 0.000 \\
\hline LOAMY SAND & \multicolumn{2}{|c|}{1 day } & \multicolumn{2}{|c|}{31 days } & \multicolumn{2}{|c|}{140 days } \\
\hline Layer & obs & $\operatorname{sim}$ & obs & $\operatorname{sim}$ & obs & $\operatorname{sim}$ \\
\hline $0-5 \mathrm{~cm}$ & 1.6 & 1.5 & 1.3 & 1.3 & 1.0 & 0.6 \\
\hline $5-15 \mathrm{~cm}$ & 0.07 & 0.00 & 0.04 & 0.01 & 0.005 & 0.05 \\
\hline $15-25 \mathrm{~cm}$ & 0.005 & 0.000 & 0.005 & 0.000 & - & 0.000 \\
\hline
\end{tabular}
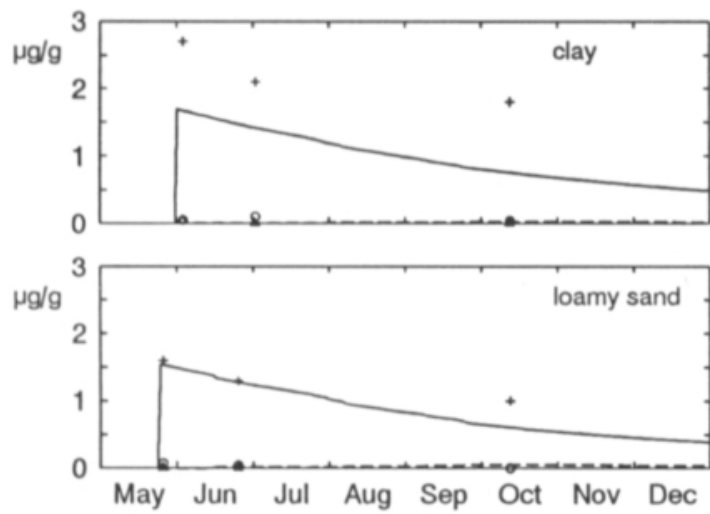

Fig. 2. Simulated trifluralin concentration $\left[\mu \mathrm{g} \mathrm{g}^{-1}\right]$ in the top soil layer (0-5 cm; solid line) and the second soil layer (5-15 cm; dashed line). The dot symbols represent observations (+: 0-5 cm; $0: 5-15 \mathrm{~cm} ; \Delta: 15-25 \mathrm{~cm})$.

are almost equal 1 day and 30 days after application. 140 days after the application the simulated concentration is clearly lower than the observed one.

Already on the first day after the application small amounts of pesticide were found also in the deeper soil layers $(5-15 \mathrm{~cm}$ and $15-25 \mathrm{~cm})$. This may be due to extremely quick leaching in sandy soils or transport through cracks in clay soils, or also due to contamination of the samples from the overlying soil layers (BRAUNSCHWEILER 1992a). Contamination might occur also in the deeper soil layers at the later sampling dates (BRAUNSCHWEILER 1992b). The model predicts that small amounts of pesticide can be found in the $5-15 \mathrm{~cm}$ layer, but no measurable amounts are simulated in the $15-25 \mathrm{~cm}$ layer during an observation period of seven months.

In Figure 3 the simulated daily runoff, the percolation below the root zone and the soil loss, used in the sensitivity runs, are shown for the period May 1987 to May 1988. The results of the sensitivity analysis can be seen in Figures 4 and 5. The effect of the variation of adsorption coefficient on the concentration in the top soil layer is small, except for very low $K_{o c}$ values (Fig. 4). When the adsorption coefficient $\mathrm{K}_{\mathrm{oc}}$ increases, the percolation (leaching below the root zone) of the pesticide decreases, whereas the pesticide loss in the eroded sediment and in the runoff water (i.e. in soluble form) increases. Note that the percolation below the root zone is displayed on a logarithmic scale, and is negligible for high values of $\mathrm{K}_{\mathrm{oc}}$. The variation of the half-life of the pesticide $t_{1 / 2}$ has a clear effect on the four studied output variables: The higher the half-life, the higher the values of the output variables (Fig. 5). 

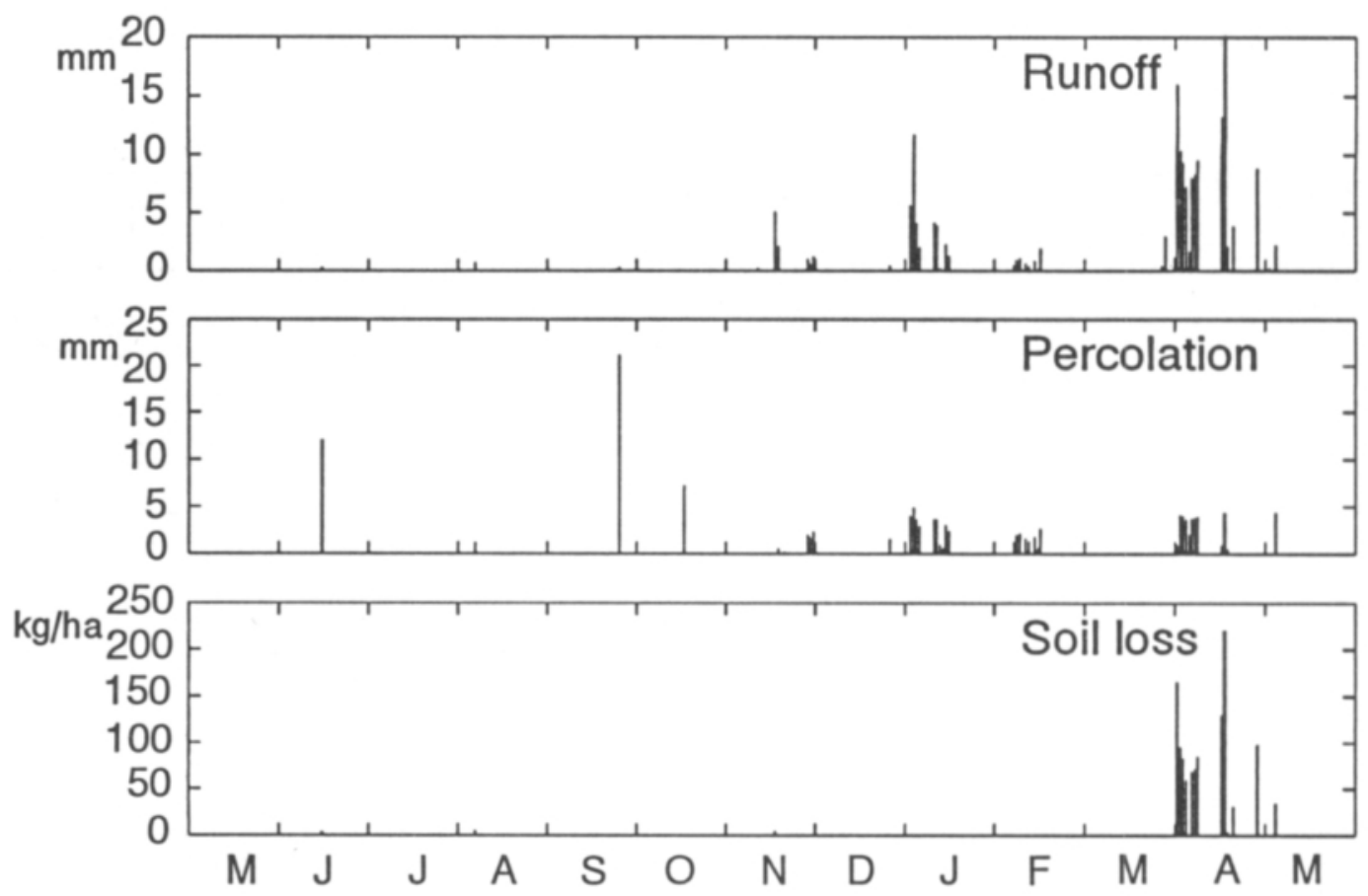

Fig. 3. Daily runoff $[\mathrm{mm}]$, percolation below the root zone $[\mathrm{mm}]$ and soil loss [ $\mathrm{kg} / \mathrm{ha}$ ] for a loamy soil, as simulated by the modified CREAMS/GLEAMS model using the temperature and precipitation shown in Figure 1.

\section{Discussion and conclusions}

There is only very limited field data on pesticide leaching available in Finland suitable for testing the pesticide component of the modified CREAMS/ GLEAMS model. The data reported by BRAUNSCHWEILER (1992a,b) used in this paper consists only of samples taken at three dates after the application, and therefore does not allow any statistical analyses of the performance of the model.

It should be noted that no model parameters were adjusted to fit the field data; only measurements and default values (DAVIS et al. 1990) were used for the model runs presented in this paper. The concentrations predicted by the model in the clay surface layer are about $1 \mu \mathrm{g} \mathrm{g}^{-1}$ lower than the observed ones, but of the same order of magnitude and with the same decreasing tendency. The reason for the underestimate might be that the bulk density was not measured, but was taken from a reference table (DAvis et al. 1990).
The simulated pesticide concentrations of the top soil layer diminish slightly faster than the observed ones. This is clearly seen in the loamy sand soil. The reason for this may be that the model does not take into account the dependence of the pesticide degradation and adsorption parameters on soil water content and soil temperature. Adsorption increases with increasing soil water content (CALVET 1989) and decreases with increasing temperature (BAILEY and WhITE 1970). The degradation rate decreases, if the water content or the temperature decreases. Especially the effect of a low temperature is considerable, and biological degradation may stop at $5^{\circ} \mathrm{C}$ (BOESTEN 1986). On the other hand, the adsorption coefficient of trifluralin is quite high and even a great variation of it has only a small effect on the concentration. Therefore, the constant pesticide degradation rate (half-life) is probably the main reason for the discrepancy between field data and model output.

The behaviour of the pesticide component of the 

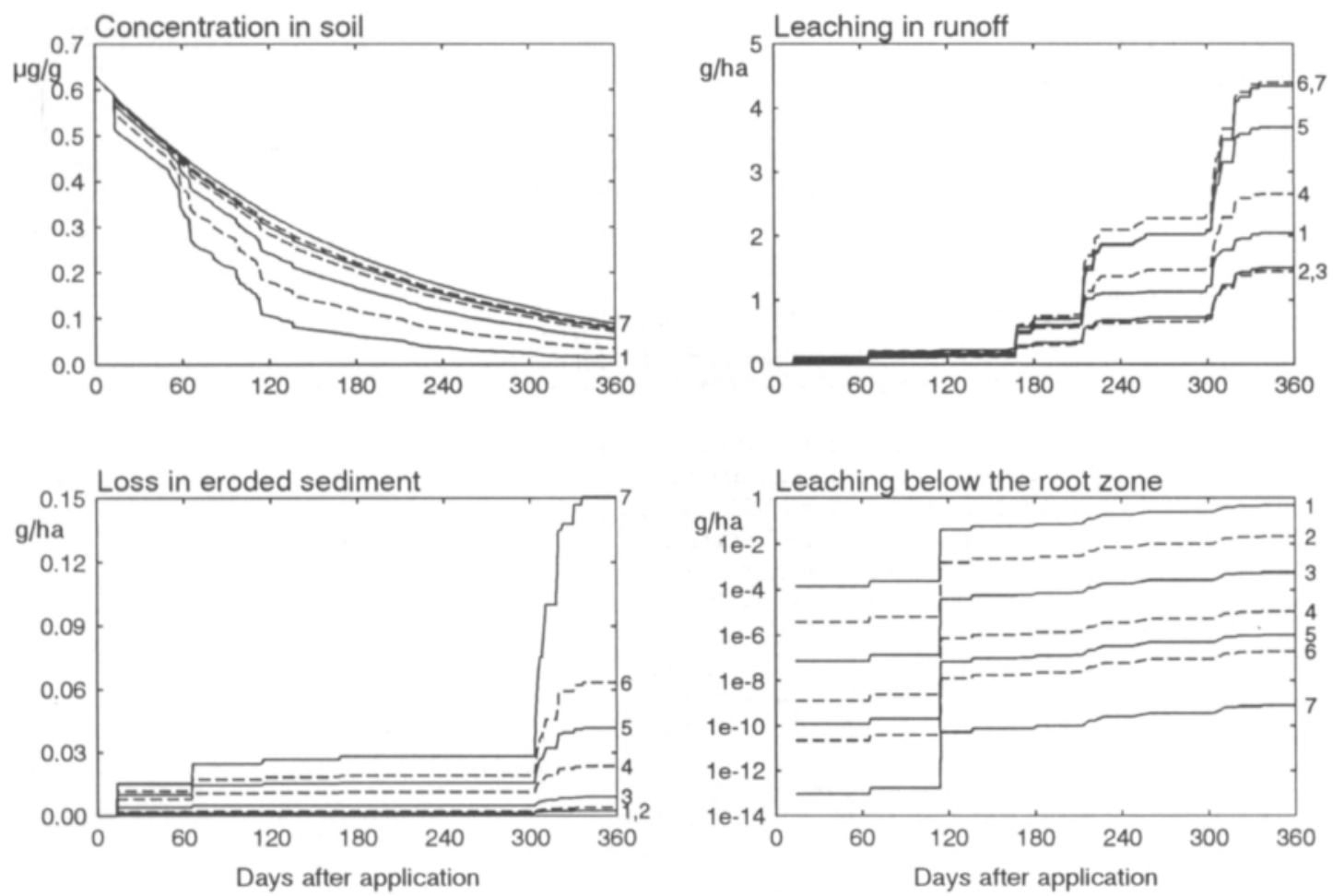

Fig. 4. The effect of varying the adsorption coefficient for organic carbon, $\mathrm{K}_{\mathrm{oc}}$, on the pesticide concentration in the soil (7.5 $\mathrm{cm}$ top layer) $\left[\mu \mathrm{g} \mathrm{g}^{-1}\right]$ and on the cumulative amounts of the pesticide leaching in runoff $\left[\mathrm{g} \mathrm{ha}^{-1}\right]$, the pesticide loss in eroded sediment $\left[\mathrm{g} \mathrm{ha}^{-1}\right]$ and the pesticide leaching below the root zone $\left[\mathrm{g} \mathrm{ha}^{-1}\right]$. The values for $\mathrm{K}_{\mathrm{oc}}$ used were 50, 100, 200, $400,600,800$ and $2000 \mathrm{ml} \mathrm{g}^{-1}$ and are labeled ' 1 ' through ' 7 '.

modified CREAMS/GLEAMS model in the sensitivity analysis, judged by four key output variables, is largely as expected. For high adsorption coefficients the pesticide concentration in the $7.5 \mathrm{~cm}$ top soil layer is determined almost solely by degradation (Eq. 3 and Fig. 4), whereas for low $\mathrm{K}_{\mathrm{oc}}$ values it is strongly influenced by runoff events as long as the concentration is still high. At low concentrations even pronounced runoff events do not decrease the concentrations any further. In the top $1 \mathrm{~cm}$ layer, which solely contributes to runoff, the concentration for low $\mathrm{K}_{\mathrm{oc}}$ values is close to zero already after a few months due to the first major runoff events and infiltration to lower soil layers. This also explains the higher losses both with surface runoff and eroded material for high $\mathrm{K}_{\mathrm{oc}}$ values at the end of the simulation period. The percolation of the pesticide out of the root zone $(40 \mathrm{~cm})$ is very sensitive to changes in the adsorption coefficient, however, the values are extremely low for high $\mathrm{K}_{\mathrm{oc}}$ values.

Note that the sensitivity analysis was carried out for one year only (May 1987 to May 1988), and therefore the results are influenced by the runoff and erosion events of that period (Fig. 3). This can also be seen from Figure 5 which shows the dependence of the four output variables on the variation in the half-life of the pesticide. For low halflife (less than 50 days) the concentration in the soil decreases rapidly and - if there is no major runoff event immediately after application - the losses will be small.

The present study shows that the current version of the pesticide module of the modified 

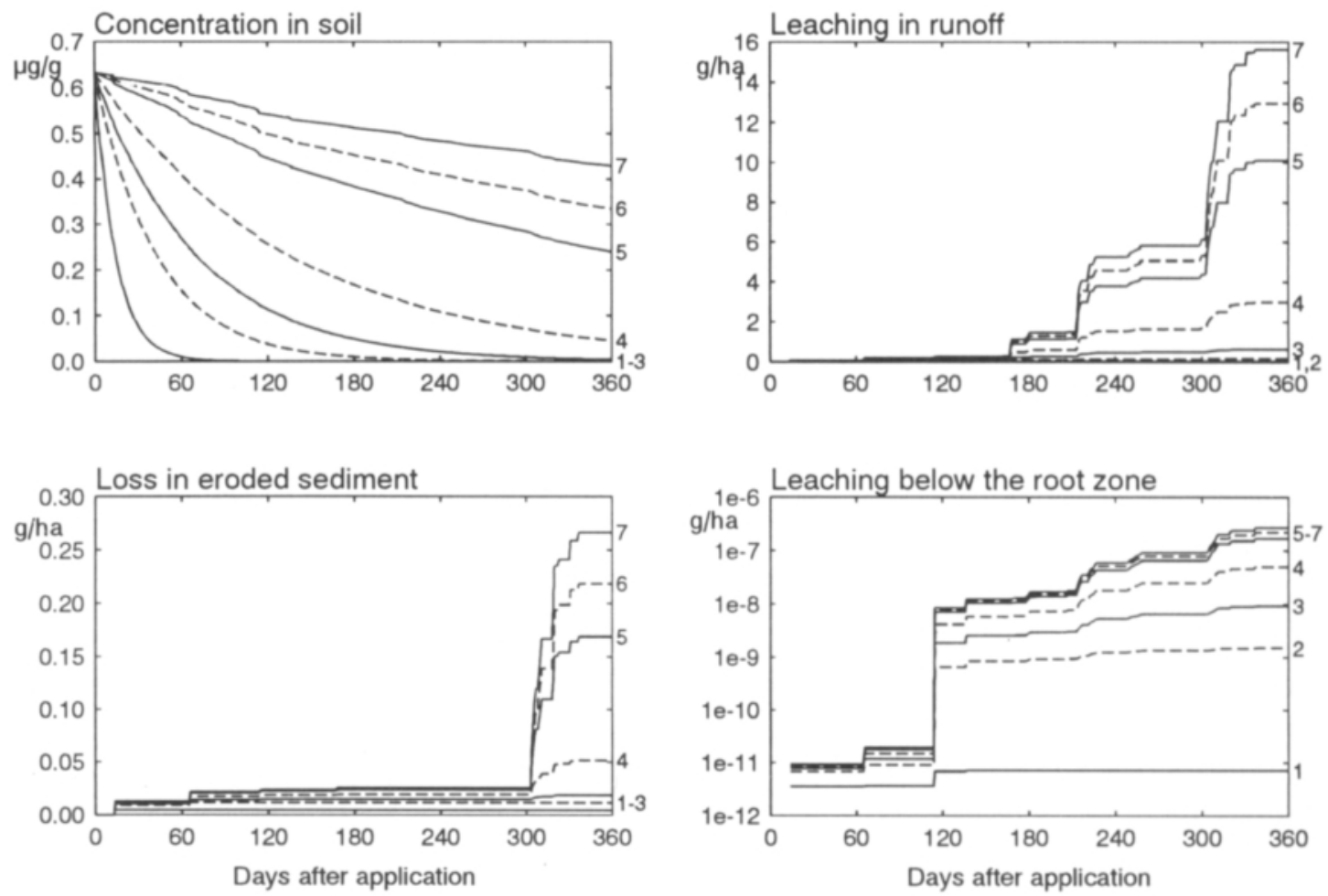

Fig. 5. The effect of varying the pesticide half-life, $\mathrm{t}_{1 / 2}$ (days), on the pesticide concentration in the soil (7.5 $\mathrm{cm}$ top layer) $\left(\mu \mathrm{g} \mathrm{g}^{-1}\right)$ and on the cumulative amount of the pesticide leaching in runoff $\left(\mathrm{g} \mathrm{ha}^{-1}\right)$, the pesticide loss in eroded sediment $\left(\mathrm{g} \mathrm{ha}^{-1}\right)$ and the pesticide leaching below the root zone $\left(\mathrm{g} \mathrm{ha}^{-1}\right)$. The values for $\mathrm{t}_{1 / 2}$ used were $10,30,50,100,300,500$, and 1000 days and are labeled ' 1 ' through ' 7 '.

CREAMS/GLEAMS model predicts pesticide concentrations in the top soil layer quite well. This encourages the model's application for the assessment of pesticide leaching and transport in the regulatory work of the responsible authorities. However, further model testing, using other field data, and model improvements - such as the implementation of a temperature dependent degradation rate - are desirable to improve the reliability of the model as a tool for the quick and inexpensive assessment of the consequences of the application of pesticides.

\section{References}

BaIley, G.W. \& Whrte, J.L. 1970. Factors influencing adsorption, desorption and movement of pesticides in soil. Residue Review 32: 29-92.

BOESTEN, J.J.T.I. 1986. Behaviour of herbicides in soil: Simulation and experimental assessment. PhD Thesis, Institute of Pesticide Research, Wageningen, The Netherlands. $263 \mathrm{p}$.

Braunschweiler, H. 1992a. The fate of some pesticides in Finnish cultivated soils. Agricultural Science in Finland 1: 37-55.
— 1992b. Eräiden torjunta-aineiden käyttäytyminen suomalaisissa viljelymaissa. Mimeograph Series of the National Board of Waters and the Environment 389, Helsinki, Finland. 67 p.

CALVEt, R. 1989. Adsorption of organic chemicals in soils. Environmental Health Perspectives 83: 145-177.

Davis, F.M., Leonard, R.A. \& Knisel, W.G. 1990. GLEAMS User Manual, Version 1.8.55, Lab Note SEWRL-030190FMD, USDA-ARS Southeast Watershed Research Laboratory, Tifton, Georgia. 62 p. 
Hynninen, E.-L. \& BlomQvist, H. 1992. Pesticide sales in Finland in 1991. Kemia-Kemi 19: 663-565.

JARVIS, N. 1991. MACRO - A Model of water movement and solute transport in macroporous soils. Swedish University of Agricultural Sciences, Department of Soil Sciences, Reports and Dissertations 9, Uppsala, Sweden. $58 \mathrm{p}$.

Kallio, K., Rekolainen, S., Posch, M. \& Turtola, E. 1989. Testing and modifying the CREAMS model for Finnish conditions. In: Beasley, D.B. et al. (eds.). Proceedings of a CREAMS/GLEAMS Symposium, Athens, Georgia. Publ. No. 4, Agricultural Engineering Department, UGA-CPES. p. 179-191.

KNISEL, W.G. (ed.) 1980. CREAMS: A Field-Scale Model for Chemical, Runoff, and Erosion from Agricultural Management Systems. U.S. Department of Agriculture, Conservation Research Report 26.640 p.

LANE, L.J. \& NeARING, M.A. 1989. USDA-Water Erosion Prediction Project: Hillslope profile model documentation. National Soil Erosion Research Laboratory, Report No. 2.

Leonard, R.A., Knisel, W.G. \& StILl, D.A. 1987. GLEAMS: Groundwater Loading Effects of Agricultural Management Systems. Transactions of the ASAE 30: 1403-1418.

Nikunen, E., Leinonen, R. \& KultamaA, A. 1990. Environmental properties of chemicals. Ministry of Environment, Research Report 91/1990, Helsinki, Finland. $1084 \mathrm{p}$.

OECD Environment Directorate 1989. Compendium of environmental exposure assessment methods for chemicals. OECD Environment Monographs No. 27. p. 149-199.

Posch, M. \& Rekolainen, S. 1993. Erosivity factor in the Universal Soil Loss Equation estimated from Finnish rainfall data. Agricultural Science in Finland 2: 271-279.
RAO, P.S.C. \& DAVIDSON, J.M. 1980. Estimation of pesticide retention and transformation parameters required in nonpoint source pollution models. In: Overcash, M.R. \& Davidson, M.J. (eds.). Environmental Impact of Nonpoint Source Pollution. Ann Arbor Science, Ann Arbor, Michigan, U.S.A. p. 23-67.

Rekolainen, S. \& Posch, M. 1992. Modelling pesticide transport to surface waters: Risk assessment and effects of management practices. In: Helweg, A. (ed.). Pesticides in the aquatic environment: appearance and effect. Seminar, Tune Landsboskole, Tidsskrift for Planteavls Specialserie, Beretning nr. S2181-1992, p. 85-92.

— \& Posch, M. 1993. Adapting the CREAMS model for Finnish conditions. Nordic Hydrology 24: 309-322.

—, Posch, M. \& Turtol. , E. 1993. Mitigation of agricultural water pollution in Finland: An evaluation of management practices. Water Science and Technology 28: 529-538.

RrTCHIE, J.T. 1972. A model for predicting evaporation from a row crop with incomplete cover. Water Resources Research 14: 533-538.

Salo, S., Posch, M. \& Rekolainen, S. 1993. PESTYM torjunta-ainemallin käyttäjöopas (User manual for the pesticide model PESTYM). Mimeograph Series of the National Board of Waters and the Environment 504, Helsinki, Finland. 29 p.

U. S. Department of Agriculture 1972. National Engineering Handbook, Section 4: Hydrology. Washington, D.C.

Wagenet, R.J. \& Hutson, J.L. 1986. Predicting the fate of non-volatile pesticides in the unsaturated zone. Journal of Environmental Quality 15: 315-322.

WischmeIER, W.H. \& S Mith, D.D. 1978. Predicting erosion rainfall losses, a guide to conservation planning. U.S. Department of Agriculture, Handbook No. 537. 58 p.

Manuscript received June 1993 
SELOSTUS

\title{
Modifioidun CREAMS/GLEAMS mallin testaus maaperän torjunta-ainepitoisuuksien ennustamisessa
}

\author{
Simo Salo, Maximilian Posch ja SePpo Rekolainen
}

Vesien- ja ympäristöntutkimuslaitos

Tutkimuksen tarkoitus oli testata suomalaisiin olosuhteisiin sovitetun CREAMS/GLEAMS torjunta-ainemallin tarkkuutta. Mallilla laskettuja torjunta-ainepitoisuuksia verrattiin kenttäkokeissa mitattuihin torjunta-ainepitoisuuksiin. Testiaineena oli trifluraliini ja tuloksia verrattiin savimaalla ja karkealla hietamaalla. Lisäksi arvioitiin mallin herkkyyttä kahden torjunta-aineparametrin suhteen. Arvioidut parametrit olivat torjunta-aineen adsorptiokerroin orgaaniseen hiileen ja torjunta-aineen puoliintumisaika maassa.

Testaustulokset osoittivat, että mallilla laskettu maan torjunta-ainepitoisuus vastasi mitattuja pitoisuuksia melko hyvin mutaman ensimmäisen viikon ajan levityksen jälkeen. Kui- tenkin noin 4,5 kuukauden kuluttua levityksestä mitatut maan torjunta-ainepitoisuudet olivat selvästi mallinnettuja pitoisuuksia suuremmat. Syy tähän on todennäköisesti se, että malli käyttää maan lämpötilasta riippumatonta torjunta-aineen hajoamiskerrointa.

Herkkyysanalyysit osoittivat, että mallin arvioima torjuntaaineiden kulkeutuminen on varsin herkkä molempien tutkittujen parametrien vaihteluille. Malli on erityisen herkkä adsorptiokertoimen vaihteluille, kun arvioidaan torjunta-aineiden kulkeutumista perkolaation mukana juuristovyöhykkeen alapuolelle. 